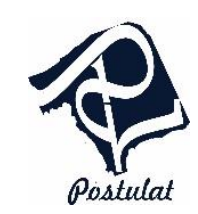

Jurnal Inovasi Pendidikan Matematika

Volume 2, Nomor 1, Juli 2021

\title{
Meningkatkan Berfikir Kritis Siswa Pada Materi Relasi dan Fungsi Menggunakan Model Problem Based Learning Di Kelas VIII SMP Negeri 2 Jeumpa
}

\author{
Nita Rozanna ${ }^{1}$ \\ SMPN 2 Jeumpa ; Jln. Simpang IV Gampong Lipah Rayeuk, Kabupaten Bireuen, Aceh \\ 24251;nita.birn112@gmail.com
}

\begin{abstract}
This study aims to improve students' critical thinking skills in relation and function material using the Problem Based Learning learning model in class VIII SMP Negeri 2 Jeumpa. This type of research is Classroom Action Research. The subjects in this study were students of class VIII SMP Negeri 2 Jeumpa. The instruments in this study were teacher activity sheets, student activity sheets, and test questions. This research was conducted in three cycles, the first cycle consisting of one meeting, the second cycle consisting of one meeting, and the third cycle consisting of one meeting. Data collection techniques in this study are the results of tests and observations. Learning is carried out offline. The results of data processing in the first cycle showed that student learning outcomes were only $50 \%$ of students who completed learning, from the results of teacher observations, namely 3.00 which was classified as good, and from the results of student observations it was obtained that $72.22 \%$ were in good criteria. In the second cycle there was an increase, namely learning outcomes that reached $70 \%$ of students who completed learning, from the results of teacher observations, namely 3.27 which was classified as good, and from the results of student observations, it was obtained $80.56 \%$. In the third cycle there was an increase again, namely the completeness of student learning outcomes as much as $90 \%$ which classically was included in the complete category, from the results of teacher observations, namely 3.60 which was classified as very good, and from the results of student observations it was obtained that $88.89 \%$ were at very good criteria. Based on the research results, it can be concluded that "Application of Problem Based Learning (PBL) Learning Model can Improve Students' Critical Thinking Ability on Relationship Materials and Functions of Class VIII SMP Negeri 2 Jeumpa".
\end{abstract}

Keywords:Problem Based Learning , Critical Thinking

\begin{abstract}
Abstrak
Penelitian ini bertujuan untuk meningkatkan kemampuan berfikir kritis siswa pada materi Relasi dan Fungsi menggunakan model pembelajaran Problem Based Learning di kelas VIII SMP Negeri 2 Jeumpa.Jenis penelitian ini adalah Penelitian Tindakan Kelas. Subjek dalam penelitian ini adalah siswa kelas VIII SMP Negeri 2 Jeumpa. Instrumen dalam penelitian ini adalah lembar aktivitas guru, lembar aktivitas siswa, dan soal tes. Penelitian ini dilaksanakan tiga siklus, siklus pertama terdiri dari satu pertemuan, siklus kedua terdiri dari satu pertemuan, dan siklus ketiga terdiri dari satu pertemuan. Teknik pengumpulan data dalam penelitian ini adalah hasil test dan hasil observasi. Pembelajaran dilaksanakan secara Luring. Hasil pengolahan data pada
\end{abstract}


Nita Rozanna: Meningkatkan Berfikir Kritis Siswa Pada Materi Relasi...

siklus I menunjukkan bahwa hasil belajar siswa hanya 50\% siswa yang tuntas belajar, dari hasil observasi guru yaitu 3,00 yang tergolong baik, dan dari hasil observasi siswa diperoleh yaitu 72,22\% yang berada pada kriteria baik. Pada siklus ke II terjadi peningkatan yaitu hasil belajar yang mencapai $70 \%$ siswa yang tuntas belajar, dari hasil observasi guru yaitu 3,27 yang tergolong baik, dan dari hasil observasi siswa diperoleh yaitu 80,56 $\%$. Pada siklus ke III terjadi lagi peningkatan yaitu ketuntasan hasil belajar siswa sebanyak $90 \%$ yang secara klasikal sudah termasuk kategori tuntas, dari hasil observasi guru yaitu 3,60 yang tergolong sangat baik, dan dari hasil observasi siswa diperoleh yaitu $88,89 \%$ yang berada pada criteria sangat baik. Berdasarkan hasilhasil penelitian dapat disimpulakan bahwa "Penerapan Model Pembelajaran Problem Based Learning (PBL) dapat Meningkatkan Kemampuan Berfikir Kritis Siswa pada Materi Relasi dan Fungsi kelas VIII SMP Negeri 2 Jeumpa".

Kata Kunci: Problem Based Learning , Berfikir kritis

INFO ARTIKEL

ISSN $: 2733-0597$
e-ISSN $: 2733-0600$
DOI $:$ http://dx.doi.org/10.30587/postulat.v2i1.2959

Submit Artikel:

2 Oktober 2020

Submit Revisi:

23 Maret 2021

Upload Artikel:

12 Juli 2021

\section{PENDAHULUAN}

Kemajuan suatu bangsa sangat ditentukan oleh kualitas sumber daya manusianya. Kualitas sumber daya manusia itu bergantung pada kualitas pendidikan. Salah satu ilmu pendidikan yang dipelajari adalah matematika. Siswa masih banyak mengalami kesulitan dalam memahami dan menerapkan pengetahuan, termasuk juga dalam pengetahuan matematika. Dalam kebanyakan ilmu pengetahuan, matematika merupakan pengetahuan yang memegang peranan penting. Matematika diperlukan untuk memenuhi kebutuhan praktis dan memecahkan masalah dalam kehidupan sehari-hari. Selain itu, matematika dapat membantu memahami bidang studi lain seperti fisika, kimia, arsitektur, farmasi, geografi, ekonomi, dan sebagainya, serta matematika membantu siswa agar dapat berpikir logis, kritis, dan praktis, beserta bersikap positif dan berjiwa kreatif. Salah satu penyebab rendahnya kualitas pendidikan matematika adalah kegiatan pembelajaran yang dilaksanakan di sekolah selama ini berorientasi pada guru. Di sisi lain, pada pembelajaran matematika sendiri juga ditemukan keragaman masalah sebagai berikut: Keaktifan siswa dalam mengikuti pembelajaran masih belum tampak, para siswa jarang mengajukan pertanyaan, walaupun 
guru sering meminta agar siswa bertanya jika ada hal-hal yang belum jelas dan kurang paham, kemampuan berfikir kritis siswa dalam mengerjakan soal-soal latihan pada proses pembelajaran juga masih kurang, kurangnya keberanian siswa untuk mengeluarkan pendapat atau menjawab pertanyaan.

Dari permasalahan tersebut, penulis menduga bahwa salah satu penyelesaian untuk meningkatkan kemampuan berfikir kritis siswa dalam materi Relasi dan Fungsi adalah dengan menerapkan model pembelajaran yang memberikan kesempatan kepada siswa untuk berlatih menyelesaikan soal secara berkelompok, karena mereka harus menganalisa dan berfikir kritis dalam menyelesaikan soal tersebut. Salah satu model pembelajaran yang dapat dilakukan adalah dengan menggunakan Model Pembelajaran Problem Based Learning.

Menurut Kamdi (2007: 77), "Problem Based Learning (PBL) merupakan model kurikulum yang berhubugan dengan masalah dunia nyata siswa. Masalah yang diseleksi mempunyai dua karakteristik penting, pertama masalah harus autentik yang berhubungan dengan kontek sosial siswa, kedua masalah harus berakar pada materi subjek dari kurikulum". Terdapat tiga ciri utama dari model Problem Based Learning (PBL).

"Pertama, problem based learning merupakan rangkaian aktivitas pembelajaran, artinya dalam implementasi PBL ada sejumlah kegiatan yang harus dilakukan siswa, siswa tidak hanya mendengar, mencatat, kemudian menghafal materi pelajaran, tetapi melalui model problem based learning (PBL) siswa menjadi aktif berpikir, berkomunikasi, mencari dan mengolah data, dan akhirnya membuat kesimpulan. Kedua, aktivitas pembelajaran diarahkan untuk menyelesaikan masalah. Problem based learning ini menempatkan masalah sebagai kata kunci dari proses pembelajaran. Artinya tanpa masalah pembelajaran tidak akan mungkin bisa berlangsung. Ketiga, pemecahan masalah menggunakan pendekatan berpikir secara ilmiah".

Menurut Nurhadi (2004: 65) "Problem based learning adalah kegiatan interaksi antara stimulus dan respons, merupakan hubungan antara dua arah belajar dan lingkungan". Lingkungan memberi masukan kepada siswa berupa bantuan dan masalah, sedangkan sistem saraf otak berfungsi menafsirkan bantuan itu secara efektif sehingga yang dihadapi dapat 
Nita Rozanna: Meningkatkan Berfikir Kritis Siswa Pada Materi Relasi...

diselidiki, dinilai, dianalisis, serta dicari pemecahannya dengan baik. PBL merupakan sebuah pendekatan pembelajaran yang menyajikan masalah konstektual sehingga merangsang siswa untuk belajar. PBL merupakan suatu model pembelajaran yang menantang siswa untuk belajar, bekerja secara berkelompok untuk mencari solusi dari permasalahan dunia nyata. Masalah ini digunakan untuk mengikat siswa pada rasa ingin tahu pada pembelajaran yang dimaksud.

Berdasarkan uraian mengenai $P B L$ di atas, dapat disimpulkan bahwa $P B L$ merupakan pembelajaran yang menghadapkan siswa pada masalah dunia nyata (real world) untuk memulai pembelajran. Masalah diberikan kepada siswa, sebelum siswa mempelajari konsep atau materi yang berkenaan dengan masalah yang harus dipecahkan. Dengan demikian untuk memeahkan masalah tersebut siswa akan mengetahui bahwa mereka membutuhkan pengetahuan baru yang harus dipelajari untuk memecahkan masalah yang diberikan.

Ada lima proses dalam penerapan metode PBL dan perilaku yang dibutuh oleh pengajar. Adapun tahapan- tahapan tersebut adalah (Sugiyanto, 2010).

Tabel 1. Sintaks Model Pembelajaran Problem Based Learning

\begin{tabular}{lll}
\hline \multicolumn{1}{c}{ Fase } & \multicolumn{1}{c}{ Prilaku pengajar } \\
\hline Fase 1 & $\begin{array}{l}\text { Memberikan orentasi } \\
\text { tentang permasalahannya } \\
\text { kepada mahasiswa }\end{array}$ & $\begin{array}{l}\text { Guru membahas tujuan pembelajaran, } \\
\text { mendeskripsikan dan memotivasi anak didik agar } \\
\text { terlibat dalam kegiatan mengatasi masalah yang } \\
\text { ada. }\end{array}$ \\
\hline Fase 2 & $\begin{array}{l}\text { Mengorganisasikan anak } \\
\text { didik untuk meniliti }\end{array}$ & $\begin{array}{l}\text { Guru membantu anak didik untuk mendefenisikan } \\
\text { dan mengorganisasikan tugas- tugas belajar yang }\end{array}$ \\
& $\begin{array}{l}\text { Merkait dengan pemrmasalahannya. } \\
\text { Fase 3 }\end{array}$ & $\begin{array}{l}\text { Guru mendorong anak didik untuk mendapatkan } \\
\text { informasi yang tepat, melakukan eksperimen dan } \\
\text { kecara mandiri atau }\end{array}$ \\
& $\begin{array}{l}\text { mencari penjelasan serta solusi untuk penyelesaian } \\
\text { masalah tersebut }\end{array}$ \\
\hline Fase 4 & $\begin{array}{l}\text { Mengembangkan dan } \\
\text { mempresentasikan hasil } \\
\text { kerja }\end{array}$ & $\begin{array}{l}\text { Guru membantu anak didik dalam merencanakan } \\
\text { dan menyiapkan hasil- hasil yang tepat, seperti } \\
\text { laporan, rekaman vidio dan model- model yang } \\
\text { mebantu mereka untuk menyampaikan kepada }\end{array}$
\end{tabular}


orang lain hasil yang mereka dapatkan untuk menyelesaikan masalah tersebut.

\begin{tabular}{lll}
\hline Fase 5 & Menganalisis dan & Guru membantu anak didik untuk melakukan \\
& mengevaluasi proses & refleksi terhadap inverstigasinya dan proses- \\
& mengatasi masalah & proses yang mereka gunakan.
\end{tabular}

Berfikir kritis adalah suatu proses dimana seseorang atau individu dituntut untuk menginterpretasikan dan mengevaluasi informasi untuk membuat sebuah penilaian atau keputusan berdasarkan kemampuan,menerapkan ilmu pengetahuan dan pengalaman. ( Pery \& Potter,2005). Menurut Bandman dan Bandman (1988), berpikir kritis adalah pengujian secara rasional terhadap ide-ide, kesimpulan, pendapat, prinsip, pemikiran, masalah, kepercayaan dan tindakan. Menurut Strader (1992), bepikir kritis adalah suatu proses pengujian yang menitikberatkan pendapat tentang kejadian atau fakta yang mutakhir dan menginterprestasikannya serta mengevaluasi pandapat-pandapat tersebut untuk mendapatkan suatu kesimpulan tentang adanya perspektif/ pandangan baru. Berpikir kritis adalah proses perkembangan kompleks yang berdasarkan pada pikiran rasional dan cermat. Menjadi pemikir kritis adalah sebuah denominator umum untuk pengetahuan yang menjadi contoh dalam pemikiran yang disiplin dan mandiri. Pengetahuan didapat, dikaji dan diatur melalui berpikir.

Jadi, yang dimaksud dengan berpikir kritis merupakan suatu tehnik berpikir yang melatih kemampuan dalam mengevaluasi atau melakukan penilaian secara cermat tentang tepat-tidaknya ataupun layak-tidaknya suatu gagasan yang mencakup penilaian dan analisa secara rasional tentang semua informasi, masukan, pendapat dan ide yang ada, kemudian merumuskan kesimpulan dan mengambil suatu keputusan. Bahwa untuk mendapatkan suatu hasil berpikir yang kritis, seseorang harus melakukan suatu kegiatan (proses) berpikir yang mempunyai tujuan (purposeful thinking), bukan "asal" berpikir yang tidak diketahui apa yang ingin dicapai dari kegiatan tersebut. Artinya, walau dalam kehidupan sehari-hari seseorang sering melakukan proses berpikir yang terjadi secara "otomatis" (misal; dalam menjawab pertanyaan "siapa namamu?") 
Nita Rozanna: Meningkatkan Berfikir Kritis Siswa Pada Materi Relasi...

Menurut Ennis (1996: 364) terdapat 6 unsur dasar dalam berpikir kritis yang disingkat menjadi FRISCO : F (Focus): Untuk membuat sebuah keputusan tentang apa yang diyakini maka harus bisa memperjelas pertanyaan atau isu yang tersedia, yang coba diputuskan itu mengenai apa. R(Reason): Mengetahui alasan-alasan yang mendukung atau melawan putusan-putusan yang dibuat berdasar situasi dan fakta yang relevan. I (Inference): Membuat kesimpulan yang beralasan atau menyungguhkan. Bagian penting dari langkah penyimpulan ini adalah mengidentifikasi asumsi dan mencari pemecahan, pertimbangan dari interpretasi akan situasi dan bukti. S (Situation): Memahami situasi dan selalu menjaga situasi dalam berpikir akan membantu memperjelas pertanyaan (dalam F) dan mengetahui arti istilahistilah kunci, bagian-bagian yang relevan sebagai pendukung. C (Clarity): Menjelaskan arti atau istilah-istilah yang digunakan. $\mathbf{O}$ (Overview): Melangkah kembali dan meneliti secara menyeluruh keputusan yang diambil. Untuk menilai kemampuan berpikir kritis Watson dan Glaser (1980) melakukan pengukuran melalui tes yang mencakup lima buah indikator, yaitu mengenal asumsi, melakukan inferensi, deduksi, interpretasi, dan mengevaluasi argumen.

Penelitian tindakan kelas ini bertujuan untuk mengetahui apakah menggunakan model pembelajaran Problem Based Learning dapat meningkatkan kemampuan berfikir kritis siswa pada materi Relasi dan Fungsi di kelas VIII SMP Negeri 2 Jeumpa.

\section{METODE PENELITIAN}

Dalam Penelitian tindakan kelas ini yang menjadi subjek penelitian adalah siswa kelas VIII/1b SMP Negeri 2 Jeumpa yang terdiri dari 10 siswa dengan komposisi 4 siswa laki-laki dan 6 siswa perempuan. Data hasil observasi guru diperoleh dari hasil observasi kemampuan guru mengelola pembelajaran, data hasil observasi aktifitas siswa diperoleh dari hasil observasi aktifitas siswa selama pembelajaran. Data hasil tes diperoleh dari hasil tes siswa yang menjadi subjek penelitian. Data yang diperlukan dalam penelitian ini dikumpulkan dengan menggunakan instrumen:

a. Lembar aktifitas guru, digunakan untuk memperoleh data tentang aktifitas guru.Berisi komponen-komponen yang perlu diamati selama pembelajaran. 
b. Lembar Aktivitas Siswa, yang digunakan adalah lembar penilaian aktifitas siswa sebagai alat untuk mengukur perkembangan aktifitas siswa terhadap proses pembelajaran pada setiap pertemuan.

c. Tes

Tes yang diberikan dalam bentuk essay. Tes ini bertujuan untuk memperoleh data tentang kemampuan berfikir kritis siswa kelas VIII SMP Negeri 2 Jeumpa dalam menyelesaikan soal-soal tentang masalah Relasi dan Fungsi.

Data yang dimaksud disini adalah hasil test dan hasil observasi. Adapun data yang diperoleh dianalisis berdasarkan fenomena dan permasalahan masing-masing berdasarkan rumusun masalah penelitian, yaitu sebagai berikut:

1. Pengolahan Data Hasil Observasi.

a) Data aktivitas guru.

Data tentang aktivitas guru mengelola pembelajaran dianalisis dengan menggunakan statistik deskriptif dengan skor rata-rata tingkat aktifitas guru, sebagaimana dikemukakan Hasratuddin (dalam Muklis, 2005:69). Adapun pendeskripsian skor rata-rata Tingkat Kemampuan Guru (TKG) adalah sebagai berikut:

$1,00 \leq \mathrm{TKG}<1,50$ kurang baik

$1,50 \leq \mathrm{TKG}<2,50$ cukup baik

$2,50 \leq \mathrm{TKG}<3,50$ baik

$3,50 \leq \mathrm{TKG}<4,00$ sangat baik

Sumber: (Mukhlis, 2005:79)

b) Data Aktifitas Siswa

Untuk mengetahui aktivitas siswa selama pembelajaran berlangsung dapat dianalisis dengan menggunakan persentase. Adapun rumus persentase menurut Sudijono (2007:28) sebagai berikut:

$$
P=\frac{F}{N} \times 100 \%
$$

Tabel 2: Kriteria Persentase Penilaian Hasil Observasi 
Nita Rozanna: Meningkatkan Berfikir Kritis Siswa Pada Materi Relasi...

\begin{tabular}{|c|c|}
\hline Persentase & Kriteria \\
\hline $81 \%-100 \%$ & Sangat Baik \\
\hline $61 \%-80 \%$ & Baik \\
\hline $41 \%-60 \%$ & Cukup Baik \\
\hline $21 \%-40 \%$ & Kurang Baik \\
\hline $0 \%-21 \%$ & Sangat Tidak Baik \\
\hline
\end{tabular}

Diadaptasi dari Riduwan (2013:41)

\section{3) Pengolahan Data Hasil Belajar Siswa}

Data hasil belajar siswa terdiri atas data hasil belajar siswa pada sikus I dan data hasil belajar siswa pada siklus II. Analisa masing-masing data hasil belajar siswa untuk setiap pertemuan ditinjau berdasarkan ketuntasan belajar siswa secara individual yang mengacu pada KKM (Kriteria Ketuntasan Minimal) yang ditetapkan disekolah yaitu 75 sedangkan ketuntasan secara klasikal, mengacu pada pendapat Mulyasa (2004:99) yang menyebutkan "Tuntas belajar secara klasikal apabila dikelas tersebut terdapat $\geq 85 \%$ dari jumlah siswa yang tuntas belajar individual". Persentase hasil belajar secara klasikal dengan rumus seperti dikemukakan sudijono (2005:43), yaitu:

$$
P=\frac{F}{N} \times 100 \%
$$

Keterangan:

$\mathrm{P}=$ Persentase ketuntasan siswa

$\mathrm{F}=$ Frekfensi siswa yang tuntas

$\mathrm{N}$ = Jumlah seluruh sampel

Pengambilan keputusan suksesnya suatu siklus jika kemampuan guru dalam mengelola pembelajaran baik dan didukung oleh aktifitas siswa yang baik dan dengan syarat ketuntasan belajar siswa dipenuhi dalam penerapan model pembelajaran Problem Based Learning pada materi Relasi dan Fungsi, Jika paling sedikit tiga aspek dari aspek-aspek ketuntasan belajar siswa, kemampuan guru dalam mengelola pembelajaran, aktifitas siswa, dengan syarat ketuntasan belajar siswa dipenuhi maka pembelajaran tersebut dikatakan efektif. Oleh karena itu, jika minimal ketiga aspek dengan syarat bahwa ketuntasan belajar 
siswa tercapai maka penerapan pendekatan saintifik pada materi Relasi dan Fungsi di kelas VIII SMP Negeri 2 Jeumpa dikatakan efektif pula.

Penelitian yang dilakukan merupakan Penelitian Tindakan Kelas (PTK) dengan menerapakan pendekatan saintifik dan model pembelajaran discovery learning untuk meningkatkan hasil belajar siswa. Arikunto (2009:58) mengatakan, "Penelitian Tindakan Kelas (PTK) adalah penelitian tindakan (action research) yang dilakukan dengan tujuan memperbaiki mutu praktik pembelajaran di kelasnya".

Prosedur penelitian ini terdiri dari empat langkah, yaitu perencanaan, tindakan, observasi, dan refleksi dari masing-masing siklus. Hal tersebut sesuai dengan yang dikemukakan oleh Arikunto (2009:70) bahwa prosedur hendaknya dirinci dari perencanaan, pelaksanaan tindakan, observasi, dan evaluasi-refleksi yang bersifat daur ulang atau siklus. Tahap-tahap siklus tersebut dapat dijelaskan sebagai berikut:

1) Perencanaan

a. Menyusun RPP lengkap (materi sesuai rumusan masalah)

b. Mempersiapkan fasilitas dan sarana pendukung

c. Merancang alat evaluasi

d. Merancang instrument observasi/pengamatan

e. Membuat scenario pembelajaran

f. Mempersiapkan cara menganalisis data

g. Melakukan simulasi pelaksanaan tindakan

2) Tindakan/pelaksanaan

a. Melaksanakan pembelajaran di kelas sesuai perencanaan

b. Melaksanakan evaluasi/tes

3) Observasi/pengamatan

Dilaksanakan bersamaan pada proses pembelajaran (diamati oleh guru atau teman sejawat), kegiatannya berupa melihat, mendengarkan, mencatat, merekam, tidak mengganggu.

Tabel 3. Observasi Kemampuan Guru Mengelola Pembelajaran 
Nita Rozanna: Meningkatkan Berfikir Kritis Siswa Pada Materi Relasi...

\begin{tabular}{|c|c|c|c|c|c|}
\hline \multirow{2}{*}{\multicolumn{2}{|c|}{ Aspek yang diamati }} & \multicolumn{4}{|c|}{ TKG } \\
\hline & & 1 & 2 & 3 & 4 \\
\hline \multicolumn{2}{|c|}{ Kegiatan Pendahuluan } & & & & \\
\hline 1 & Kemampuan memotivasi siswa & & & & \\
\hline 2 & $\begin{array}{l}\text { Kemampuan menghubungkan pembelajaran saat ini dengan } \\
\text { pembelajaran sebelumnya }\end{array}$ & & & & \\
\hline 3 & $\begin{array}{l}\text { Kemampuan menginformasikan langkah-langkah } \\
\text { pembelajaran }\end{array}$ & & & & \\
\hline \multicolumn{2}{|r|}{ Kegiatan Inti } & & & & \\
\hline 4 & $\begin{array}{l}\text { Kemampuan menjelaskan materi/soal/masalah dengan model } \\
\text { Problem Besed Learning }\end{array}$ & & & & \\
\hline 5 & $\begin{array}{l}\text { Kemampuan mengarahkan siswa untuk menemukan jawaban } \\
\text { dan cara menjawab soal }\end{array}$ & & & & \\
\hline 6 & $\begin{array}{l}\text { Kemampuan membimbing siswa dalam menyelesaikan } \\
\text { masalah secara berdiskusi kelompok }\end{array}$ & & & & \\
\hline 7 & Kemampuan mengoptimalkan interaksi siswa dalam bekerja & & & & \\
\hline 8 & Kemampuan memimpin diskusi kelas/ menguasai kelas & & & & \\
\hline 9 & Kemampuan menghargai berbagai pendapat & & & & \\
\hline 10 & $\begin{array}{l}\text { kemampuan mengarahkan siswa untuk menemukan sendiri } \\
\text { dan menarik kesimpulan }\end{array}$ & & & & \\
\hline 11 & $\begin{array}{l}\text { Kemampuan mendorong siswa untuk mau bertanya } \\
\text { mengeluarkan pendapat atau menjawab pertanyaan }\end{array}$ & & & & \\
\hline 12 & kemampuan mengajukan dan menjawab pertanyaan & & & & \\
\hline \multicolumn{2}{|r|}{ Penutup } & & & & \\
\hline 13 & $\begin{array}{l}\text { kemampuan menegaskan hal-hal yang penting yang berkaitan } \\
\text { dengan pembelajaran }\end{array}$ & & & & \\
\hline 14 & Kemampuan mengelola waktu & & & & \\
\hline 15 & kemampuan mengelola suasana kelas & & & & \\
\hline
\end{tabular}

Keterangan:

$1=$ kurang baik

$2=$ cukup

$3=$ baik

4 = sangat baik

TKG = Tingkat Kemampuan Guru

Tabel 4. Observasi Aktivitas Siswa Selama Kegiatan Pembelajaran 


\begin{tabular}{|c|l|c|c|c|c|}
\hline \multirow{2}{*}{ No } & \multicolumn{1}{|c|}{ Kategori Pengamatan } & \multicolumn{3}{|c|}{$\begin{array}{c}\text { Aktivitas siswa dalam } \\
\text { pembelajaran }\end{array}$} \\
\cline { 3 - 5 } & & 1 & 2 & 3 & 4 \\
\hline 1 & Mendengarkan/memperhatikan penjelasan guru/teman & & & & \\
\hline 2 & Membaca/memahami masalah di LKPD & & & & \\
\hline 3 & $\begin{array}{l}\text { Menyelesaikan masalah atau menemukan solusi } \\
\text { pemecahan masalah secara berkelompok }\end{array}$ & & & & \\
\hline 4 & Bekerjasama dalam mengerjakan LKPD & & & & \\
\hline 5 & $\begin{array}{l}\text { Bertanya/menyampaikan pendapat/ide kepada guru atau } \\
\text { teman sekelompok }\end{array}$ & & & & \\
\hline 6 & $\begin{array}{l}\text { Menarik kesimpulan suatu konsep yang ditemukan atau } \\
\text { suatu prosedur yang telah dikerjakan }\end{array}$ & & & & \\
\hline 7 & Siswa mencari informasi & & & & \\
\hline 8 & $\begin{array}{l}\text { Percaya diri/berani mengemukakan pendapat/ide di depan } \\
\text { kelas }\end{array}$ & & & & \\
\hline 9 & Bertanya kepada guru tentang hal yang belum dipahami & & & & \\
\hline & Jumlah & & & & \\
\hline
\end{tabular}

Keterangan :

$1=$ kurang baik

$2=$ cukup

$3=$ baik

4 = sangat baik

4) Refleksi

a. Menjawab penyebab kondisi yang terjadi

b. Merenungkan kembali kekuatan dan kelemahan tindakan

c. Memperkirakan keluhan yang ada

d. Mengidentifikasi kendala/ ancaman yang mungkin dihadapi

e. Memperkirakan akibat dan implikasi tindakan yang direncanakan

f. Hasil refleksi digunakan untuk rencana siklus berikutnya

Keempat langkah tersebut menurut Arikunto (2009:74) dapat digambarkan sebagai beikut: 
Nita Rozanna: Meningkatkan Berfikir Kritis Siswa Pada Materi Relasi...

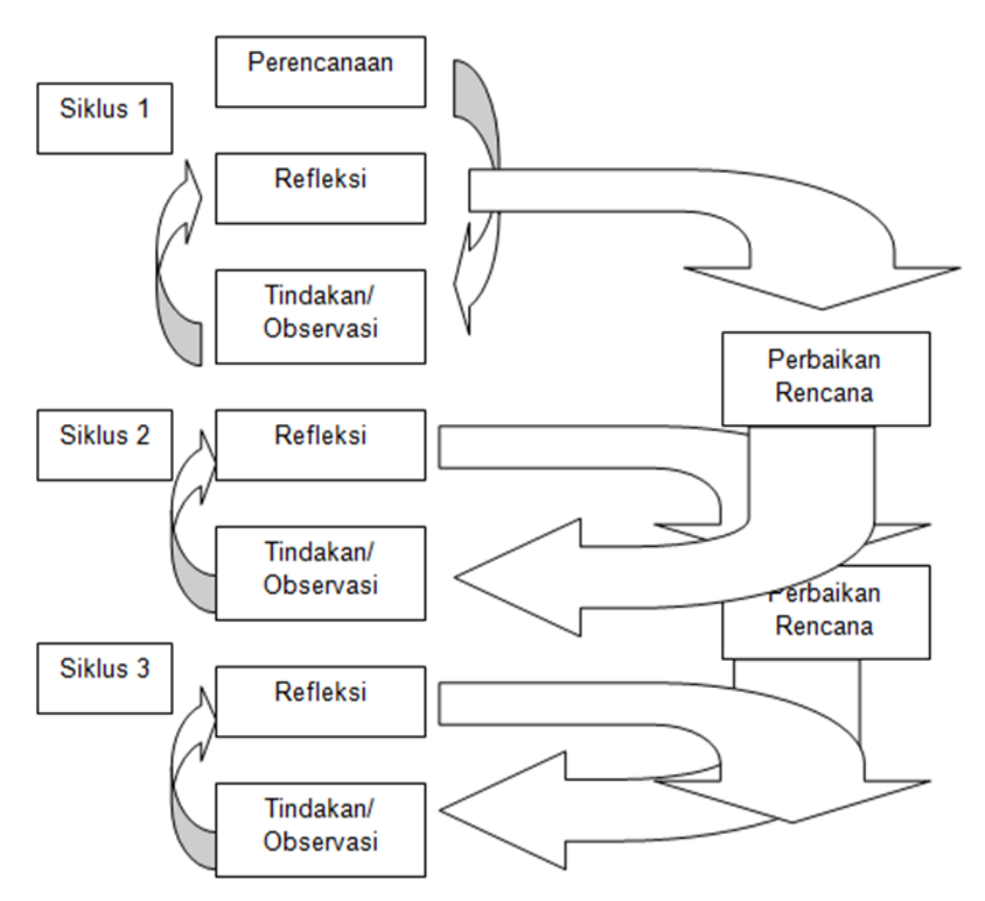

Gambar 1. Siklus PTK

Prosedur penelitian tindakan kelas yang akan dilakukan dalam penelitian ini terdiri dari tiga siklus, dimana setiap siklus akan dilaksanakan empat langkah seperti yang telah diuraikan di atas.

\section{HASIL PENELITIAN}

Setelah melaksanakan siklus I, siklus II, dan Siklus III menggunakan model pembelajaran Problem Based Learning terdapat peningkatan persentase ketuntasan belajar (peningkatan kemampuan berfikir kritis) siswa, hasil observasi guru dan siswa yang dapat terlihat pada Tabel berikut ini:

Tabel 5. Peningkatan persentase Observasi Guru, Siswa, dan ketuntasan belajar matematika siswa dari siklus I ke siklus II dan ke siklus III

\begin{tabular}{|l|c|c|c|c|c|c|}
\hline Jenis Instrumen & Siklus I & Kriteria & Siklus II & Kriteria & Siklus III & Kriteria \\
\hline Observassi Guru & $75 \%$ & Baik & $81.75 \%$ & Baik & $90 \%$ & Sangat Baik \\
\hline Observasi Siswa & $72.22 \%$ & Baik & $80.56 \%$ & Baik & $88.89 \%$ & Sangat Baik \\
\hline Hasil Belajar & $50 \%$ & Tidak Tuntas & $70 \%$ & Tidak tuntas & $90 \%$ & Tuntas \\
\hline
\end{tabular}




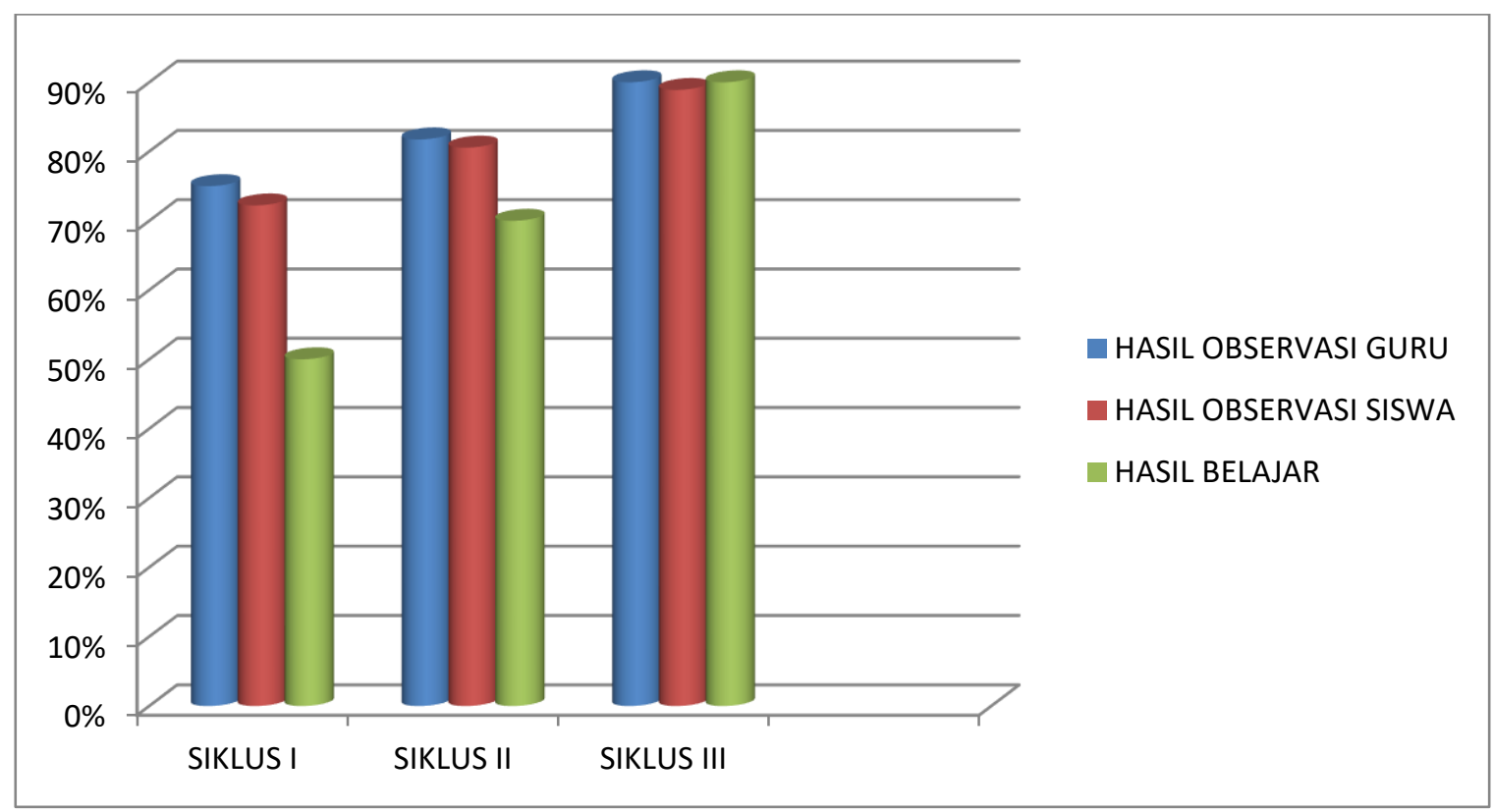

Gambar 2. Persentase Hasil Observasi Guru, Siswa, dan ketuntasan belajar matematika siswa dari siklus I ke siklus II dan ke siklus III

Berdasarkan tabel dan gambar diatas dapat dilihat bahwa terjadi peningkatan tiap siklus, pada persentase hasil belajar menunjukkan bahwa pada siklus ketiga baik secara klasikal maupun KKM nilai siswa sudah tercapai, karena siswa yang memperoleh nilai $\geq 75$ sebesar $90 \%$. Hasil ini sudah diatas presentase ketuntasan klasikal yang telah ditetapkan yaitu $85 \%$, sehingga dapat disimpulkan secara klasikal sudah termasuk kategori tuntas. Hasil ini menunjukkan bahwa pada siklus III telah tuntas baik secara klasikal maupun KKM, walaupun ada siswa yang belum tuntas namun hasil evaluasi siswa meningkat dari hasil evaluasi pada siklus I dan II, maka penelitian ini dikatakan telah berhasil dan cukup sampai siklus III. Sehingga dapat dikatakan secara keseluruhan pelaksanaan pembelajaran dengan model pembelajaran Problem Based Learning ini dapat dinilai positif dan baik karena sebagian besar siswa tertarik dan sangat bersemangat dalam belajar.

\section{KESIMPULAN, DISKUSI DAN REKOMENDASI}

Penelitian tindakan kelas tentang "Meningkatkan Berfikir Kritis Siswa pada Materi Relasi dan Fungsi Menggunakan Model Pembelajaran Problem Based Learning di Kelas 
Nita Rozanna: Meningkatkan Berfikir Kritis Siswa Pada Materi Relasi...

VIII/1 SMP Negeri 2 Jeumpa" telah dilaksanakan. Dimana hasil penelitian menunjukan terjadinya peningkatan berfikir kritis siswa dengan penerapan Model Pembelajaran Problem Based Learning (PBL). Hal ini berdasarkan dari hasil belajar matematika siswa terjadi peningkatan rata-rata hasil belajar yaitu pada siklus I 50\% menjadi 70\% pada siklus II dan 90\% pada siklus III serta sudah mencapai kategori sangat baik.

Berdasarkan kesimpulan yang diperoleh dari penelitian ini, maka penulis memberikan saran sebagai berikut:

- Guru hendaknya turut serta untuk terus menciptakan atau mengembangkan perangkat dengan model Problem Based Learning (PBL) yang sesuai dengan kondisi sekolah setempat sehingga dapat meningkatkan kemampuan berfikir kritis siswa terhadap matematika yang akan berdampak meningkatnya prestasi belajar.

- Hendaknya guru SMP Negeri 2 Jeumpa lebih aktif dalam menerapkan pendekatan terbaru.

- Guru hendaknya dapat memotivasi siswa dengan tepat sehingga siswa dapat membangun sendiri pemahamannya dan akan lebih aktif

- Kepala sekolah disarankan untuk mengambil langkah-langkah agar para guru senantiasa dapat menerapkan pendekatan-pendekatan yang dapat meningkatkan hasil belajar siswa.

\section{UCAPAN TERIMA KASIH}

Terima kasih kepada semua pihak yang telah banyak membantu penulis dalam proses penyelesaian karya tulis ini. Semoga semua kebaikan tersebut diberi imbalan oleh Allah SWT. Tentu saja karya tulis ini banyak kekurangan, oleh sebab itu saran dan kritik selalu diharapkan. Akhirul kalam semoga karya yang sederhana ini dapat bermanfaat.

\section{DAFTAR PUSTAKA}

Anas, Sudijono. (2005). Pengantar Evaluasi Pendidikan. Jakarta: Paja Grafindo.

Arikunto, Suharsimi. 2010. Prosedur Penelitian Suatu Pendekatan Praktek. Jakarta: Rineka Cipta.

Ennis, R.H. (1996) A Critical Thinking. New York: Freeman 
Kamdi. Malang: Universitas Negeri Malang, 2008. 63, 2008. Model-model Pembelajaran Inovatif. W Kamdi. Malang: Universitas Negeri Malang, 2007

Maulana, 2012. Efektifitas Model Pembelajaran NHT pada Materi Himpunan di Kelas VII SMP Negeri 2 Langsa. "Skripsi mahasiswa tidak dipublikasikan". Banda Aceh: Universitas Syiah Kuala.

Mulyasa, E. 2002. Kurikulum Berbasis Kompetensi, Konsep, Karakteristik, dan Implementasi. Bandung: Remaja Rosdyakarya.

Mukhlis Abdul. (Ed).2005:5 .Penelitian Tindakan Kelas. Kemmis and MC Taggart.1998. The Action Research Planner. Dekan University.

Nurhadi. 2004. Kurikulum 2004.Jakarta: PT Grasindo.

Potter \& Perry. (2005). Buku Ajar Fundamental Keperawatan Konsep, Proses, dan. Praktik. Edisi 4 volume 1.EGC. Jakarta. Almatsier

Riduwan. 2013. Dasar-Dasar Statistika. Bandung: Alfabeta.

Sanjaya, W. 2006. Strategi Pembelajaran. Jakarta: Kencana Prenada Media Group. Semiawan, C. 1995. Pendekatan Ketrampilan Proses. Jakarta : Gramedia

Trianto (2009).Mendesain Model Pembelajaran Inovatif Progresif. Surabaya: Kencana

Tri Rusmi. 1996. Perilaku Manusia. Jakarta : Candra Pratama 